\title{
Changes in Preparation and Practice Patterns Among New Family Physicians
}

\author{
Amanda K. H. Weidner, MPH \\ Frederick M. Chen, MD, MPH \\ Family Medicine Residency Network, \\ Department of Family Medicine, University \\ of Washington, Seattle, Washington
}

\begin{abstract}
Family physicians' scope of practice is declining despite being well prepared to provide a range of clinical services. To evaluate whether this is a new phenomenon, we compared the proportions of regional family medicine residency graduates who report practicing and those who report feeling more than adequately prepared to practice various procedures and clinical services from 2 points in time-a survey in 2000 of graduates from 1996-1999 $(n=293)$ and a survey in 2012 or 2014 of graduates from 2010-2013 $(n=408)$. The recent graduates felt better prepared, but reported a narrower scope of practice than those who graduated more than a decade earlier. These findings suggest that family medicine residency training has improved over time but the declining scope of practice is a concerning trend.
\end{abstract}

Ann Fam Med 2019;17:46-48. https://doi.org/10.1370/afm.2337.

\section{INTRODUCTION}

$\mathrm{T}$ he decline in family physicians' scope of practice in the United States over the last few decades has been well documented, with fewer family physicians practicing obstetrics, pediatrics, hospital care, and house calls..$^{1-5}$ At the same time, numerous studies have examined family medicine residency graduates' preparation for practice, ${ }^{1,6-9}$ and a recent national report identified a clear gap between preparation and scope of practice, with graduates feeling well-prepared for clinical services that they are not using in practice. ${ }^{10}$

This study looks at the difference between both preparation for and the scope of practice among new family medicine residency graduates at 2 points in time, 2000 and 2012-2014.

\section{METHODS}

Every 2 to 3 years the University of Washington Family Medicine Residency Network surveyed the most recent classes of graduates on behalf of its affiliated programs in Washington, Wyoming, Alaska, Montana, and Idaho. The survey addressed what graduates are doing in their current medical practice in a variety of services and procedures. The survey also asked graduates to rate their preparation for practice for the same list.

This retrospective cross-sectional study compares practice patterns and feelings of preparation between 2 cohorts of University of Washington Family Medicine Residency Network graduate survey respondents: those who graduated residency between 2010 and $2013(\mathrm{n}=408)$ and completed the 2012 or 2014 survey (later cohort), and those who graduated between 1996 and 1999 and completed the 2000 survey (earlier cohort).

We used the z-test for proportions to compare demographic characteristics and the differences between cohorts who reported that a service or procedure was part of their current practice and who reported feeling more than adequately prepared for practicing them. Depending on survey year, the scale for the preparation question has changed from a 3- to a 5-point scale, though all used underprepared as the lowest option, adequately pre- 
Table 1. Characteristics of Respondent Family Physician Cohorts

\begin{tabular}{lccc}
\hline Characteristic & 1996-1999 & 2010-2013 & P Value \\
\hline Response rate, \% (No.) & $74(293)$ & $76(408)$ & .486 \\
Male, \% (No.) & $48(142)$ & $41(167)$ & $.048^{\mathrm{a}}$ \\
Years since residency graduation, mean y & 2.14 & 1.98 & .657 \\
Board certified by ABFM or AOBFP, \% (No.) & $93(272)$ & $94(383)$ & .584 \\
Practice size, \% (No.) & & & \\
Solo or 2 physician partnership & $10(28)$ & $5(19)$ & $.011^{\text {a }}$ \\
Single specialty group & $35(104)$ & $29(120)$ & .090 \\
Multispecialty group & $28(83)$ & $39(158)$ & $.005^{\text {b }}$ \\
Other (locums, military, residency, etc) & $18(53)$ & $27(111)$ & $.005^{\text {b }}$ \\
Practice community size, \% (No.) & $16(47)$ & $14(59)$ & .565 \\
$<5,000$ & $22(65)$ & $23(93)$ & .849 \\
$5,001-<25,000$ & $24(70)$ & $22(91)$ & .623 \\
$25,001-<100,000$ & $32(93)$ & $40(163)$ & $.027^{\text {a }}$ \\
$\geq 100,000$ \& suburbs & & & \\
\hline ABFM = American Board of Family Medicine; AOBFP = American Osteopathic Board of Family Physicians. & \\
a P <.05 & & \\
bP $<.01$ &
\end{tabular}

pared as the middle option, and well prepared as the highest option. For the purposes of this study, we grouped responses that were more than "adequately prepared for practice" for our comparisons. Reported proportions were from those who responded to the question; missing data for any question was $5 \%$ or less. The $t$-test was used to compare mean years since residency graduation at time of survey.

This project was reviewed and approved under expedited review by the University of Washington Institutional Review Board.

\section{RESULTS}

The surveys compared in this study all had $>70 \%$ response rates. There are

Table 2. Proportions of Cohorts Feeling More Than Adequately Prepared for Practice by Residency Training and Practicing Listed Services and Procedures at Time of Survey

\begin{tabular}{|c|c|c|c|c|c|c|c|c|}
\hline \multirow[b]{2}{*}{$\begin{array}{l}\text { Services and } \\
\text { Procedures }\end{array}$} & \multicolumn{4}{|c|}{ More Than Adequately Prepared for Practice } & \multicolumn{4}{|c|}{ Part of Practice at Time of Survey } \\
\hline & $\begin{array}{c}1996-1999 \\
\text { Cohort, \% (N) }\end{array}$ & $\begin{array}{c}2010-2013 \\
\text { Cohort, \% (N) }\end{array}$ & $\begin{array}{c}\text { Change, } \\
\%\end{array}$ & $\begin{array}{c}P \\
\text { Value }\end{array}$ & $\begin{array}{c}1996-1999 \\
\text { Cohort, \% (N) }\end{array}$ & $\begin{array}{c}2010-2013 \\
\text { Cohort, \% (N) }\end{array}$ & $\begin{array}{c}\text { Change, } \\
\%\end{array}$ & $\begin{array}{c}P \\
\text { Value }\end{array}$ \\
\hline \multicolumn{9}{|l|}{ Women's health } \\
\hline Prenatal care & $73(215)$ & 87 (356) & 14 & $<.001$ & $76(222)$ & $57(232)$ & -19 & $<.001$ \\
\hline Deliveries & $63(185)$ & $83(337)$ & 20 & $<.001$ & $70(205)$ & $45(182)$ & -25 & $<.001$ \\
\hline C-delivery, primary & $9(27)$ & $11(43)$ & 2 & .565 & $10(30)$ & $10(41)$ & 0 & .935 \\
\hline C-delivery, assist & $53(156)$ & $68(278)$ & 15 & $<.001$ & $61(180)$ & $38(155)$ & -23 & $<.001$ \\
\hline OB ultrasound & $7(20)$ & 27 (112) & 20 & $<.001$ & $19(55)$ & 27 (112) & 8 & .008 \\
\hline Newborn CPR & $24(70)$ & $40(162)$ & 16 & $<.001$ & $70(204)$ & $62(252)$ & -8 & .032 \\
\hline Colposcopy & $28(81)$ & $52(212)$ & 24 & $<.001$ & $52(153)$ & 47 (193) & -5 & .200 \\
\hline LEEP/LEETZ & $7(20)$ & $17(71)$ & 10 & $<.001$ & $12(35)$ & $9(38)$ & -3 & .261 \\
\hline DEC & $9(25)$ & $13(53)$ & 4 & .065 & $23(66)$ & $10(39)$ & -13 & $<.001$ \\
\hline Termination & $6(19)$ & $13(51)$ & 7 & .009 & $5(14)$ & $6(25)$ & 1 & .443 \\
\hline \multicolumn{9}{|l|}{ Services } \\
\hline Ambulatory care & $70(206)$ & $91(371)$ & 21 & $<.001$ & $95(277)$ & 97 (396) & 2 & .094 \\
\hline Inpatient medicine & $63(185)$ & $88(358)$ & 25 & $<.001$ & $78(228)$ & $46(186)$ & -32 & $<.001$ \\
\hline Emergency care & 37 (107) & $54(219)$ & 17 & $<.001$ & $64(187)$ & $38(153)$ & -26 & $<.001$ \\
\hline Intensive/ICU-CCU & $25(72)$ & $46(186)$ & 21 & $<.001$ & $58(170)$ & $24(96)$ & -34 & $<.001$ \\
\hline Nursing home care & $27(78)$ & $59(242)$ & 32 & $<.001$ & $52(152)$ & $33(134)$ & -19 & $<.001$ \\
\hline End-of-life care & $38(111)$ & $75(308)$ & 37 & $<.001$ & $77(225)$ & $84(342)$ & 7 & .020 \\
\hline Surgery/assist & $40(118)$ & 48 (195) & 8 & .049 & $48(140)$ & $20(82)$ & -28 & $<.001$ \\
\hline Disability evaluation & $3(8)$ & $14(59)$ & 11 & $<.001$ & $61(179)$ & $54(219)$ & -7 & .052 \\
\hline Orthopedics & $21(61)$ & 41 (169) & 20 & $<.001$ & 94 (274) & 76 (309) & -18 & $<.001$ \\
\hline \multicolumn{9}{|l|}{ Procedures } \\
\hline Sigmoidoscopy & $24(71)$ & $7(30)$ & -17 & $<.001$ & $42(124)$ & $4(16)$ & -38 & $<.001$ \\
\hline Full colonoscopy & $3(10)$ & $10(39)$ & 7 & .002 & $5(14)$ & $6(25)$ & 1 & .443 \\
\hline Treadmill stress test & $16(48)$ & $12(48)$ & -4 & .080 & $26(75)$ & $10(40)$ & -16 & $<.001$ \\
\hline Intubation & $19(56)$ & $24(96)$ & 5 & .163 & $39(113)$ & $23(92)$ & -16 & $<.001$ \\
\hline Manage ventilator & $9(25)$ & $14(57)$ & 5 & .028 & $25(72)$ & $14(59)$ & -11 & .001 \\
\hline Central line & $11(31)$ & $16(66)$ & 5 & .035 & $20(59)$ & $16(67)$ & -4 & .207 \\
\hline Interpret radiograph & $23(68)$ & $51(209)$ & 28 & $<.001$ & $91(266)$ & 85 (346) & -6 & .020 \\
\hline
\end{tabular}


some differences in demographic and practice characteristics between the earlier and later cohorts of graduates (Table 1).

Significant differences exist between the proportion of the earlier and later cohorts who report practicing various services and procedures at the time of the survey (Table 2). The earlier cohort had a similar or significantly higher proportion of graduates practicing almost all of the listed services and procedures than the later cohort; only obstetric ultrasound and end-oflife care were more common among the later cohort.

The opposite pattern was observed when comparing the proportions of graduates who felt more than adequately prepared for practice, where a greater proportion of those in the later cohort reported feeling more than adequately prepared in most areas (Table 2 ).

\section{DISCUSSION}

This study compared responses of 2 cohorts of new family physicians 12 to 14 years apart about how prepared for practice they felt and what they were doing in their practice at the time of the survey. We found that the recent cohort of graduates felt more prepared for practice than their earlier counterparts, but that the recent graduates had a much narrower scope of practice than those who graduated before 2000 .

This suggests that training has improved over the last decade; it also suggests that scope of practice is declining for reasons other than lack of training. Changes in clinical practice and evidence over the last 2 decades may explain some of our findings, such as the decline in use of flexible sigmoidoscopy. The difference in practice size/type may also play a role. The trend toward practicing in larger, multispecialty groups means that family physicians may not be required (or allowed) to practice all they learned in residency.

As with all cross-sectional studies, this study cannot prove causality. There is also the possibility of response bias and an issue of generalizability, in this case to other parts of the United States. This study also has the potential for social desirability bias, as respondents may have reported feeling more prepared or practicing a broader scope of care than is true given that the surveys were sent on behalf of their residency programs.

The decline in scope of practice has negative implications for the breadth and richness of individual physicans' practices, as well as for patients' access to care and quality of care. Although our training programs have succeeded in training a broad range of physican skills, these results suggest we may need to consider ways to adapt our current training to a new generation of practice realities and physician preferences.

To read or post commentaries in response to this article, see it online at http://www. AnnFamMed.org/content/17/1/46.

Key words: family practice; internship and residency; professional practice gaps; surveys and questionnaires

Submitted June 4, 2018; submitted, revised, October 4, 2018; accepted November 1, 2018.

Previous presentation: Poster presentation at the University of Washington Department of Family Medicine Scholarship Forum; April 11, 2018; Seattle, Washington.

Acknowledgments: The authors thank and acknowledge Mark Beard, $M D$, for his contribution to the original idea for this project and his review during the early stages of data analysis.

\section{References}

1. Chen FM, Huntington J, Kim S, Phillips WR, Stevens NG. Prepared but not practicing: declining pregnancy care among recent family medicine residency graduates. Fam Med. 2006;38(6):423-426.

2. Ringdahl E, Delzell JE Jr, Kruse RL. Changing practice patterns of family medicine graduates: a comparison of alumni surveys from 1998 to 2004. J Am Board Fam Med. 2006;19(4):404-412.

3. Bazemore AW, Makaroff LA, Puffer JC, et al. Declining numbers of family physicians are caring for children. J Am Board Fam Med. 2012;25(2):139-140.

4. Tong STC, Makaroff LA, Xierali IM, et al. Proportion of family physicians providing maternity care continues to decline. J Am Board Fam Med. 2012;25(3):270-271.

5. Carek PJ. Potentially alarming trends in the scope of practice for family physicians. J Am Board Fam Med. 2018;31(2):178-180.

6. Carney PA, Waller E, Dexter E, et al. Team training in family medicine residency programs and its impact on team-based practice post-graduation. Fam Med. 2017;49(5):346-352.

7. Carek PJ, Diaz V, Dickerson LM, Peterson L, Johnson S. Preparation for practice in family medicine: before and after duty hours. Fam Med. 2012;44(8):539-544.

8. Kim S, Phillips WR, Stevens NG. Family practice training over the first 26 years: a cross-sectional survey of graduates of the University of Washington Family Practice Residency Network. Acad Med. 2003; 78(9):918-925.

9. Tucker W, Diaz V, Carek PJ, Geesey ME. Influence of residency training on procedures performed by South Carolina family medicine graduates. Fam Med. 2007;39(10):724-729.

10. Peterson LE, Fang B, Puffer JC, Bazemore AW. Wide gap between preparation and scope of practice of early career family physicians. J Am Board Fam Med. 2018;31(2):181-182. 